\title{
Relationship between Innovation, Quality Practices and Firm Performance: A Study of Service Sector Firms in Pakistan
}

\author{
Mohammad Waqas Raja \\ Public Affairs School, University of Science and Technology of China \\ 96 Jinzhai Road, Hefei, Anhui, China \\ E-mail: mwaqasraja@hotmail.com \\ Song Wei \\ Public Affairs School, University of Science and Technology of China \\ 96 Jinzhai Road, Hefei, Anhui, China \\ E-mail: songwei@ustc.edu.cn
}

Received: August 16, $2014 \quad$ Accepted: Oct. 15, $2014 \quad$ Published: October 16, 2014

doi:10.5296/jmr.v6i4.6325 URL: http://dx.doi.org/10.5296/jmr.v6i4.6325

\begin{abstract}
This study explains the relationship between innovations, quality practices and firm performance of service sector firms in Pakistan. The study discusses various types of innovation practices in the service sector based on the Oslo manual and then different types of quality practices based on the EFQM model for quality excellence. In this study a detailed questionnaire was developed to measure the relationship between innovations, quality practices and firm's performance and data was collected from 157 service sector firms offering different types of services. The data was analyzed using different descriptive and inferential statistical techniques and reliability test, factor analysis, correlation analysis and regression analysis. The results show that innovations like organizational innovations have a positive relationship among management leadership, policy and strategy for quality then other innovation types while innovation results, employee results have a more positive relationship with process innovations and employee management techniques. Finally the study discusses the limitations and scope for future research in the area.
\end{abstract}

Keywords: Innovation, Total Quality Management, Service sector, Performance 


\section{Introduction}

Words like innovation and creativity are used extensively these days in every forum whether we talk about the service sector or studies from the manufacturing industry and a very tightly linked concept with innovation and creativity is quality, in short if the innovation or creativity does not bring improvement in the quality of a firms service such innovation and creativity is useless. This study is an effort to look into the relationship between innovation and quality improvement practices, and to see how different types of innovation strategies and quality practices strengthen each other or vice versa. As we know many firms from different countries now a day's faces high levels of competition and find themselves in a direct competition with both local and international competitors and the reason for this intense competition lies in fast technological changes and globalization of trade Hippel (2012). In this scenario in order to survive firms must show higher level of efficiency at low cost to produce customer oriented novel products/services that are innovative as well as cost effective. There are many different management philosophies which can help firms achieve this goal and total quality management is among one of these philosophies.

\section{Theoretical Background}

Studies in the area of innovation from private as well as public sectors has greatly improved our understanding about the processes underlying innovation and how they affects the companies' performance, but many researchers like Windrum (2008) suggests that public sector innovations are implemented by regulated frameworks and many public sector innovations for example the introduction of internet has helped in other breakthroughs but still these service innovations in public sector are considered not very significant as compared to private sector innovations in the manufacturing sector, one reason for such arguments is that many researchers have concentrated their efforts to explain the private sector innovations and their affects on businesses and economies. Other researchers like Gallouj and Djellal (2010) explains how the private sector innovation methodologies can still apply in the public sector, in their study they explained how the different approaches i.e. demarcation, assimilation and integration are useful in explaining public sector innovations as well, Miles (2007) explains how services are not very different from products and it may not always be easy to isolate or distinguish them from each other as many services cannot be provided with the help of other associated products so many product innovation methodologies are linked to service innovations as well. While according to Chen (2009) public services are only considered effective when they are efficient. Therefore the innovation in services are closely linked to another important concept that is performance and when we look at the literature about performance improvement there are many different tools and techniques among which quality improvement techniques are one of them. Researchers like Gill (2009) discusses the relationship among various quality practices and business profits, he explains the five pillars of TQM which include product, price, organization, leadership and commitment that leads to higher profits by the use of different quality improvements and customer focus. Leusar (2009) discusses how the quality excellence models are used as a guide to improve performance. The study explains different dimensions of quality models e.g. technical and social factors which include different criteria i.e. leadership, policy and strategy, people management, process 
management, partnership and resources. Zehir (2010) investigate the relationship among TQM practices, innovation and employee performance and explains how different TQM practices i.e. leadership, training, employee management, information and analysis, supplier management, process management, customer focus, and continuous improvements effects on employee performance which leads to higher innovation performance and this in later stages effects the firm overall performance. Parast (2010) concludes that technological quality improvement projects enhance technological innovation capability of the firm however they are beneficial for those firms operating in a stable environment and he also found that quality programs mainly focus on existing customers they may resist innovation for new customers.

\section{Objective of Study}

Different studies from various industries have shown that quality practices have a positive relationship with firm's performance especially its innovation performance but others have found a negative relationship as well so the main objective of this paper is to collect data from different service sector firms in Pakistan and check which quality practices have a more stronger relationship with different types of innovations. Therefore firstly this study has reviewed various research studies undertaken in the area of quality management and firm innovation practices and then designed a research questionnaire to collect data from various service providers which will help to answer the following questions.

- Which quality management practices and innovation strategies are frequently used in the service sector firms in Pakistan?

- Which innovation practices are more efficient in terms of results in enhancing firm's performance?

- Which quality practices are more efficient in terms of results in enhancing firm's performance?

- Which conditions can make TQM and innovation practices relationship positive and vice versa?

According to Porter innovation is equal to invention plus commercialization, innovation can be a new product or service or an improvement in them and many innovation do not come from laboratory but from the market place so if these new inventions and properly commercialized they become innovations.

\section{Main type of innovation}

According to the Oslo Manual there are four types of innovations: product innovations, process innovations, marketing innovations and organizational innovations.

4.1 Product/Service innovation is the introduction of a good or service that is new or significantly improved with respect to its characteristics or intended uses. This includes significant improvements in technical specifications, components and materials, incorporated software, user friendliness or other functional characteristics. Product innovations can utilize new knowledge or technologies, or can be based on new uses or combinations of existing 
knowledge or technologies. The term "product" is used to cover both goods and services. Product innovations include both the introduction of new goods and services and significant improvements in the functional or user characteristics of existing goods and services.

4.2 Process innovation is the implementation of a new or significantly improved production or delivery method. This includes significant changes in techniques, equipment and/or software. Process innovations can be intended to decrease unit costs of production or delivery, to increase quality, or to produce or deliver new or significantly improved products. Process innovations include new or significantly improved methods for the creation and provision of services. They can involve significant changes in the equipment and software used in services-oriented firms or in the procedures or techniques that are employed to deliver services. According to Rycroft (2006) Examples are the introduction of GPS tracking devices for transport services, the implementation of a new reservation system in a travel agency, and the development of new techniques for managing projects in a consultancy firm.

4.3 Marketing innovation is the implementation of a new marketing method involving significant changes in product design or packaging, product placement, product promotion or pricing. Marketing innovations are aimed at better addressing customer needs, opening up new markets, or newly positioning a firm's product on the market, with the objective of increasing the firm's sales. The distinguishing feature of a marketing innovation compared to other changes in a firm's marketing instruments is the implementation of a marketing method not previously used by the firm. It must be part of a new marketing concept or strategy that represents a significant departure from the firm's existing marketing methods. The new marketing method can either be developed by the innovating firm or adopted from other firms or organizations. New marketing methods can be implemented for both new and existing products.

4.4 Organizational innovation is the implementation of a new organizational method in the firm's business practices, workplace organization or external relations. The distinguishing features of an organizational innovation compared to other organizational changes in a firm is the implementation of an organizational method (in business practices, workplace organization or external relations) that has not been used before in the firm and is the result of strategic decisions taken by management. Organizational innovations in business practices involve the implementation of new methods for organizing routines and procedures for the conduct of work. These include, for example, the implementation of new practices to improve learning and knowledge sharing within the firm. An Example is the first implementation of practices for codifying knowledge, e.g. establishing databases of best practices, lessons and other knowledge, so that they are more easily accessible to others.

Source: Oslo Manual, A joint publication of OECD and Euro stat, Third Edition, 2005. 


\section{Typologies of service sector innovations}

There are certain typologies which are specifically used for the service sector innovations by different researchers like Gault (2012), Tether (2003, Kuch and Hauknes (2005), which are discussed below.

5.1 Service innovations Means the introduction of a new service or an improvement in the existing services of the firm.

5.2 Service Delivery innovations Means adopting new ways of delivering the services or interacting with the firm users.

5.3 Administrative / Organizational / policy innovation This involves the introduction of new organizational principles for the production and delivery of services. And include new policy concepts, programs and reforms.

5.4 Conceptual innovations Is the development of new world views that challenges innovations that undermine existing services, processes and organizational forms.

5.5 Systematic Innovations This involves new and improved ways of interacting with other organizations like universities, R\&D organizations and other knowledge basis for innovations.

\section{What Total Quality Management Is?}

Quality management is one of the most popular and durable management concepts and it has passed through a number of phases since 1920,s. The roots of quality management go back to the teachings of Drucker, Juran, Deming, Ishikawa, Crosby, Feigenbaum and countless other people that have studied, practiced, and tried to refine the process of organizational management. Before exploring the different quality management practices it is better to understand what is meant by the term quality and different people interpret quality differently and few authors had defined quality in measurable terms that can be operationalized.

Various practitioners have defined quality in different ways for example according to Joseph $\mathrm{M}$. Juran quality means "Fitness for use." where fitness is defined by the customer. According to Philip B. Crosby quality means "conformance to requirements." But the requirements may not fully represent customer expectations and Crosby treats this as a separate problem. According to Genichi Taguchi quality means "uniformity around a target value." The idea is to lower the standard deviation in outcomes, and to keep the range of outcomes to a certain number of standard deviations, with few exceptions. In today's business world there is a growing recognition that isolated improvements in particular aspects of the organization are no longer adequate and that a holistic strategy is needed to bring competitive advantage and this can be done by adopting a comprehensive model for quality implementation, evaluation and results.

\subsection{The Quality Excellence Models}

These days' practitioners working in the field of quality management are using quality models to assess and evaluate the contribution of quality practices in achieving better organizational results, and among these models the Deming application prize, MBNQA model also known as Baldrige award and the EFQM excellence model are mostly used. In this study we used the 
dimensions of the EFQM model to access the effect of quality practices on firm performance. These include Leadership, Strategy, People Management, Partnership \& Resources, Process, Products \& Service Management, Results (Customer, People, Society, Key Performance Results).

\subsubsection{Management Leadership}

Management leadership is an important factor among the quality practices and successful implementation of quality practices requires effective change in the organizational culture which is impossible without the support and commitment of the top management. Many researchers like Esin and Zehir (2010), Leticia (2007) have taken leadership as an important factor and explained how efficient leaders develop and facilitate the achievement of mission and vision and how they develop organizational values and systems required for sustainable success and implement these by their actions and behaviors.

\subsubsection{Employee Management}

Human resource development is one of the most important critical success factors among the quality practices which help in improving business and management processes. The results derived from previous researches show that people management has a very strong positive effect on over all organization performance. Researchers like Hipp (2000) noted that people management was significantly and positively correlated with financial performance of the insurance companies.

\subsubsection{Policy and Strategy}

Among the quality practices policy and strategy development are very important. Successful organizations implement their mission and vision by developing a stakeholder focused strategy that takes into account of the market and sector in which they are operating and policies, plans, objectives and processes are developed and used to implement the core strategy.

Leticia (2007) and Kumar (2009), found that strategic planning is among the quality practices that does have a significant effect on firm's performance.

\subsubsection{Partnership and Resources}

Partnerships and effective utilization of organizational resources are among one of the most important quality practices. Successful organizations form alliances with partners and collaborate in the market in an attempt to achieve competitive advantage and make long term relationships with their suppliers to resolve quality related problems.

Liusar (2009) suggested that better relationships with suppliers have helped Chinese manufactures to achieve competitive advantage in both international and domestic markets. According to Abrunhosa (2008) the just in time (JIT) concept and global competition for resources are two reasons for the importance of integrating supplier in the decision making process of the organization and now a day's organizations are expected to have their supplier seek certification too.

\subsubsection{Process Management}


The organizations who implement quality practices effectively give lots of attention to process management and they design, manage and improve processes in order to fully satisfy and guarantee increasing value for customers and stakeholders. Process management includes preventive and proactive approaches of quality management such as designing fool proof and stable production schedules and work distribution to reduce variations and improve product quality. Hung (2009) studied the effect of process management in the IT industries of China and found a significant positive relationship between statistical process controls and product quality.

\section{2, Performance Results}

According the EFQM model the performance results are measured by the following dimensions of business performance.

6.2.1 Customer's Results: The quality of a product or service is dependent on the customer expectation and satisfaction in contrast with other suppliers, so when judging customer results it depends who are the customers. According to Parast (2010) customer results can be measured by the level of improvement in client satisfaction and communication and by the reduction of their grievances and complaints.

6.2.2 Employee Results: Employees are one of the most important parts of any organization according to Prajogo (2006) and Psychogios (2010) the center of quality initiatives lies the human aspects and no quality activity can be carried out effectively if the people involved are not willing and able to contribute. While Pinho (2008) say that the success of quality initiative is dependent on the skills and motivations as well as the degree of participation and empowerment of its work force.

6.2.3 Financial Results: The previous researches have shown strong positive relationship between quality improvements and financial performance of a firm. According to Sila (2007) and Posmas (2009) firms that focus on improving the quality of their product and processes leads to improve revenues and reduction of costs.

6.2.4 Society Results: Many quality practices help firms to improve their firm's image in the society as well and the firm stands as a responsible member of the community. According to Smith (2004) the sub constructs for measuring society results include implementation of equal rights policies, adaptation of environmental protection policies, and sponsoring activities which are beneficial for the society.

\section{Methodology}

The main goal of this study is to explain the relationship between innovation activities, quality practices and firm performance in the service sector, for this purpose primary data was collected and a detailed questionnaire was developed having 54 items that are used to measure 14 constructs. The first nine items are used to get a detail demographic profile of the data collected, while the next fourteen item measure different constructs for innovation like service innovation, process innovation, marketing innovation and organizational innovations and fifteen items are used to measure different constructs for quality practices like leadership 
management, policy and strategy, employee management, partnership \& resources, process management, and the last fifteen items are used to measure different dimensions of firm performance like (Innovation results, customer, people, society, key financial results). In this study data was collected from universities, hospitals, banks, police station, telecommunication firms and transport firms and the total sample size is 157 . The respondents were senior managers working either as quality assurance managers or operation managers. For data analysis SPSS 16.0 was used.

\section{Types of Innovations}

Product/Service innovation

Process innovation

Marketing innovation

Organizational innovation

\section{Dimensions of the EFQM model}

Management Leadership
Employee Management
Policy and Strategy
Partnership and Resources
Process Management

Management Leadership

Employee Management

Policy and Strategy

Process Management

Table 1. Demographic Profile of service sector firms in Pakistan

\begin{tabular}{|l|l|l|}
\hline Type of firms Service & Frequency & Percentage \\
\hline Banks & 43 & $27 \%$ \\
\hline Hospitals & 25 & $15 \%$ \\
\hline Universities & 22 & $14 \%$ \\
\hline Telecommunication & 30 & $20 \%$ \\
\hline Police/ law enforcement & 10 & $7 \%$ \\
\hline Transport & 27 & $17 \%$ \\
\hline Total & 157 & $100 \%$ \\
\hline Area of Responsibility & Frequency & Percentage \\
\hline Quality Assurance Managers & 62 & $39 \%$ \\
\hline Operation Managers & 90 & $58 \%$ \\
\hline Others & 5 & $3 \%$ \\
\hline Total & 157 & $100 \%$ \\
\hline Number Of Employees & Frequency & Percentage \\
\hline 1000- 3000 & 0 & $0 \%$ \\
\hline $3001-6000$ & 0 & $0 \%$ \\
\hline
\end{tabular}

Innovation Results

Customer's Results

Employee Results

Society Results

Financial Results

\section{Conceptual Framework}

\section{Dimensions of Firm Performance}




\begin{tabular}{|l|l|l|}
\hline $6001-9000$ & 30 & $20 \%$ \\
\hline $9001-12000$ & 46 & $29 \%$ \\
\hline $12001-M o r e$ & 81 & $51 \%$ \\
\hline Total & 157 & $100 \%$ \\
\hline Years of Operations & Frequency & Percentage \\
\hline 2 years & 0 & $0 \%$ \\
\hline 4 years & 0 & $0 \%$ \\
\hline 6 years & 20 & $13 \%$ \\
\hline 8 or more years & 137 & $87 \%$ \\
\hline Total & 157 & $100 \%$ \\
\hline $\begin{array}{l}\text { Years implementing } \\
\text { innovations }\end{array}$ & Frequency & Percentage \\
\hline 2 years practices andity & & \\
\hline 4 years & 15 & $10 \%$ \\
\hline 6 years & 5 & $3 \%$ \\
\hline 8 or more years & 0 & $0 \%$ \\
\hline Total & 137 & $87 \%$ \\
\hline
\end{tabular}

From table 1 we can see that in the sample population $27 \%$ firms are from the banking services while $20 \%$ are from telecommunication, $17 \%$ transportation, $15 \%$ medical, $14 \%$ education, $7 \%$ from law enforcement services. Among the respondents $58 \%$ are working as operations managers while $39 \%$ are quality managers. Most firms are medium to large size with about 51\% firms having more than twelve thousand employees while $29 \%$ firms are medium size and have employees less then twelve thousand and more than nine thousand and $20 \%$ firms have employees between six to nine thousand. Almost $87 \%$ firms are operating for more than eight years and $13 \%$ are operating for last six years. $87 \%$ firms are implementing quality and innovation practices for more than eight years while others have started it from last two to four years.

Table 2. Reliability analysis of constructs for innovation, quality practices and firms performance

\begin{tabular}{|l|l|l|l|l|}
\hline S. No & Construct & $\begin{array}{l}\text { No of } \\
\text { Items }\end{array}$ & Cronbach's Alpha & $\begin{array}{l}\text { Average inter scale } \\
\text { correlations }\end{array}$ \\
\hline 1 & Service innovation & 3 & .736 & .501 \\
\hline 2 & Process innovation & 4 & .724 & .551 \\
\hline 3 & Marketing innovation & 3 & .700 & .465 \\
\hline 4 & Organization innovation & 4 & .855 & .642 \\
\hline 5 & Management Leadership & 3 & .888 & .707 \\
\hline 6 & Employee Management & 3 & .706 & .501 \\
\hline 7 & Policy Strategy & 3 & .714 & .551 \\
\hline 8 & Partnership and Resources & 3 & .705 & .465 \\
\hline 9 & Process Management & 3 & .755 & .642 \\
\hline 10 & Innovation Results & 3 & .709 & .547 \\
\hline
\end{tabular}




\begin{tabular}{|l|l|l|l|l|}
\hline 11 & Customer Results & 3 & .788 & .707 \\
\hline 12 & Employee Results & 3 & .730 & .501 \\
\hline 13 & Society Results & 3 & .794 & .551 \\
\hline 14 & Financial Results & 4 & .740 & .465 \\
\hline
\end{tabular}

To check the internal consistency of measurement items we have used cronbach alpha value, and its coefficient value should be above.7 in order for the scale to have internal consistency and from table 2 we can see that for almost all constructs the cronbach alpha value lies between.70 to.88 which shows that all items are internally consistent and there average inter scale correlation values are also high ranging from.46 to.70.

Table 3. Factor Analysis for innovation, quality practices and firms performance

\begin{tabular}{|c|c|c|c|c|c|}
\hline \multirow{2}{*}{ S. No } & \multirow{2}{*}{$\begin{array}{l}\text { Component } \\
\text { Service innovation (SI) } \\
(\mathrm{KMO})=.669 \\
\end{array}$} & \multirow{2}{*}{$\begin{array}{l}\text { Eigen } \\
\text { value }\end{array}$} & \multirow{2}{*}{$\begin{array}{l}\% \quad \text { of } \\
\text { variance } \\
\end{array}$} & \multicolumn{2}{|c|}{ Component Matrix Retained } \\
\hline & & & & Item & Component \\
\hline 1 & & 2.46 & 49.3 & SI1 & .616 \\
\hline 2 & & 1.28 & 25.7 & SI2 & .757 \\
\hline \multirow[t]{2}{*}{3} & & .555 & 11.0 & SI3 & .718 \\
\hline & $\begin{array}{l}\text { Process innovation }(\mathrm{PI}) \\
(\mathrm{KMO})=.709\end{array}$ & & & Item & Component \\
\hline 1 & & .913 & 22.7 & PI1 & .773 \\
\hline 2 & & .991 & 19.82 & PI2 & .626 \\
\hline 3 & & .833 & 16.66 & PI3 & .691 \\
\hline \multirow[t]{2}{*}{4} & & .625 & 12.5 & PI4 & 631 \\
\hline & $\begin{array}{l}\text { Marketing innovation(MI) } \\
(\mathrm{KMO})=.732\end{array}$ & & & Item & Component \\
\hline 1 & & 2.37 & 39.6 & MI1 & .691 \\
\hline 2 & & 1.12 & 18.7 & MI2 & .604 \\
\hline \multirow[t]{2}{*}{3} & & .907 & 15.1 & MI3 & .665 \\
\hline & $\begin{array}{l}\text { Organization } \\
\text { innovation(OI) } \\
(\mathrm{KMO})=.801 \\
\end{array}$ & & & Item & Component \\
\hline 1 & & 3.48 & 58.12 & OI1 & .729 \\
\hline 2 & & 1.06 & 17.7 & $\mathrm{OI2}$ & .772 \\
\hline 3 & & .520 & 8.67 & OI3 & .727 \\
\hline \multirow[t]{2}{*}{4} & & .426 & 7.10 & $\mathrm{OI} 4$ & .682 \\
\hline & $\begin{array}{l}\text { Management } \quad \text { Leadership } \\
(\mathrm{ML}) \\
(\mathrm{KMO})=.872\end{array}$ & & & Item & Component \\
\hline 1 & & 3.89 & 64.9 & ML1 & .718 \\
\hline 2 & & .694 & 11.5 & ML2 & .790 \\
\hline 3 & & .557 & 9.28 & ML3 & .759 \\
\hline
\end{tabular}




\begin{tabular}{|c|c|c|c|c|c|}
\hline & $\begin{array}{l}\text { Employee Management } \\
(\mathrm{EM})(\mathrm{KMO})=.688\end{array}$ & & & Item & Component \\
\hline 1 & & .555 & 11.0 & EM1 & .718 \\
\hline 2 & & .335 & 7.00 & EM2 & .821 \\
\hline \multirow[t]{2}{*}{3} & & .333 & 6.66 & EM3 & .838 \\
\hline & $\begin{array}{l}\text { Policy Strategy (PS) } \\
(\mathrm{KMO})=.786\end{array}$ & & & Item & Component \\
\hline 1 & & .833 & 16.65 & PS1 & .693 \\
\hline 2 & & .625 & 12.5 & PS2 & .631 \\
\hline \multirow[t]{2}{*}{3} & & .411 & 8.21 & PS3 & .619 \\
\hline & $\begin{array}{ll}\text { Partnership } & \text { and } \\
\text { Resources(PR) } \\
(\mathrm{KMO})=.702\end{array}$ & & & Item & Component \\
\hline 1 & & .675 & 11.2 & PR1 & .659 \\
\hline 2 & & .518 & 8.63 & PR2 & .797 \\
\hline \multirow[t]{2}{*}{3} & & .395 & 6.57 & PR3 & .689 \\
\hline & $\begin{array}{l}\text { Process Management }(\mathrm{PM}) \\
(\mathrm{KMO})=.801\end{array}$ & & & Item & Component \\
\hline 1 & & .426 & 7.10 & PM1 & .682 \\
\hline 2 & & .300 & 4.99 & PM2 & .837 \\
\hline \multirow[t]{6}{*}{3} & & .203 & 3.38 & PM3 & .867 \\
\hline & $\begin{array}{l}\text { Innovation Results (IR) } \\
(\mathrm{KMO})=.780\end{array}$ & & & Item & Component \\
\hline & & .539 & 12.2 & IR1 & .755 \\
\hline & & .677 & 9.56 & IR2 & .649 \\
\hline & & .400 & 10.0 & IR3 & .630 \\
\hline & $\begin{array}{l}\text { Customer Results (CR) } \\
(\mathrm{KMO})=.711\end{array}$ & & & Item & Component \\
\hline 1 & & .921 & 19.82 & CR1 & .626 \\
\hline 2 & & .834 & 16.66 & CR2 & .691 \\
\hline \multirow[t]{2}{*}{3} & & .605 & 12.5 & CR3 & .631 \\
\hline & $\begin{array}{l}\text { Employee Results (ER) } \\
(\mathrm{KMO})=.732\end{array}$ & & & Item & Component \\
\hline 1 & & .807 & 15.1 & ER1 & .765 \\
\hline 2 & & .605 & 21.2 & ER2 & .659 \\
\hline \multirow[t]{2}{*}{3} & & .518 & 8.03 & ER3 & .797 \\
\hline & $\begin{array}{l}\text { Society Results (SR) } \\
(\mathrm{KMO})=.762\end{array}$ & & & Item & Component \\
\hline 1 & & .620 & 8.07 & SR1 & .790 \\
\hline 2 & & .526 & 6.10 & SR2 & .782 \\
\hline 3 & & .800 & 4.97 & SR3 & .637 \\
\hline
\end{tabular}




\begin{tabular}{|l|l|l|l|l|l|}
\hline & $\begin{array}{l}\text { Financial Results (FR) } \\
(\text { KMO) }=.771\end{array}$ & & & Item & Component \\
\hline 1 & & 5.48 & 13.12 & FR1 & .629 \\
\hline 2 & & .906 & 19.7 & FR2 & .672 \\
\hline 3 & & .820 & 6.97 & FR3 & .767 \\
\hline 4 & & .526 & 9.10 & FR4 & .652 \\
\hline
\end{tabular}

Factor analysis is used to show the strength of the inter correlation among the item the factorability of data is also checked by the statistical test of Kaiser Meyer Olkins (KMO) index range from 0 to 1 with.6 suggested as the minimum value for a good factor analysis it shows which factor we should retain in our analysis and factor loadings greater than.6 on a factor indicate high convergent validity. According to table 3 the KMO value for the service innovation is. 669 which shows that the items have high degree of inter item correlation and all items measure the same concept with their factor loadings for SI1,SI2,SI3 as.616,.757,.718 showing high degree of convergent validity. For process innovation the KMO value is.709 and factor loading for items PI1,PI2,PI3,PI4 are.773,.626,.691,.631 showing high degree of inter item correlation and convergent validity. For marketing innovation and organization innovation the KMO values are.732 and.801 and their factor loading for ranges from.604 to.772 showing high degree of inter item correlation and convergent validity. Similarly for the quality constructs like management leadership the KMO value is.872 and factor loadings for ML1,ML2, ML3 are.718,.790,.759 631 showing high degree of inter item correlation and convergent validity for the items. For employee management the KMO value is.688 and factor loading for items EM1, EM2, EM3 are.718,.828,.831 showing high degree of inter item correlation and convergent validity for the items. Similarly the KMO value for other quality constructs like policy strategy, partnership and resources, and process management are.786,.702,.801 which shows that the items have high degree of inter item correlation for these constructs and their factor loadings ranges from.619 to.867 showing high degree of convergent validity for the items. For the performance results which are measured by five constructs i.e. innovation results, customer results, employee results, society results and financial results the KMO values are.780,.711,.732,.762,.771 respectively showing high degree of inter item correlation for these constructs and their factor loadings ranges from.626 to.797 showing high degree of convergent validity for the items.

The main objective of this study is to access the relationship between different quality and innovation practices with the firm performance results so to achieve this objective the study has used persons' correlation test to check the strength of relationship among the constructs for quality, innovation and performance. From table 4 we can see that the value. 41 shows that there is a positive significant relationship between organizational innovations and firm process innovation which indicates that firms which introduce organization innovations in policy matters these practices intern affect the firms processes too. For quality practices like management leadership we can see that it has strong positive relationship with all four types of innovations and the correlation values are all significant for SI,PI, MI,OI i.e..45,.63,.65,.78 respectively, which shows that firms where leadership is committed to quality improvement the firm innovation results also improve. similarly for employee management we can see it also 


\section{Macrothink Institute ${ }^{\mathrm{TM}}$}

has strong positive relationship with all four types of innovations and the correlation values are all significant for SI,PI,MI,OI i.e..55,.68,.59,.71 respectively, which shows that firms where employee management techniques are used for quality improvement the firm innovation results also improves. For policy and strategy it has strong positive relationship with the four types of innovations and the correlation values are all significant for SI,PI,MI,OI i.e..56,.66,.44,.79 respectively.

Table 4. Pearson correlation test between innovation, quality practices and firms performance indicators

\begin{tabular}{|c|c|c|c|c|c|c|c|c|c|c|c|c|c|c|}
\hline & SI & PI & MI & OI & ML & EM & PS & PR & PM & IR & CR & ER & SR & FR \\
\hline SI & 1 & & & & & & & & & & & & & \\
\hline PI & .28 & 1 & & & & & & & & & & & & \\
\hline MI & .38 & .20 & 1 & & & & & & & & & & & \\
\hline OI & .39 & $.41^{* *}$ & .36 & 1 & & & & & & & & & & \\
\hline ML & $.45^{* *}$ & $.63^{* *}$ & $.65^{* *}$ & $\begin{array}{l}.78^{*} \\
*\end{array}$ & 1 & & & & & & & & & \\
\hline EM & $.55^{* *}$ & $.68^{* *}$ & $.59^{* *}$ & $.71^{*}$ & $.53^{* *}$ & 1 & & & & & & & & \\
\hline PS & $.56^{* *}$ & $.66^{* *}$ & $.44^{* *}$ & $.79^{*}$ & $.52^{* *}$ & .20 & 1 & & & & & & & \\
\hline PR & $.64^{* *}$ & $.51^{* *}$ & $.65^{* *}$ & $\begin{array}{l}.57^{*} \\
*\end{array}$ & .10 & .22 & .34 & 1 & & & & & & \\
\hline PM & $.57^{* *}$ & $.67^{* *}$ & $.46^{* *}$ & ${ }_{*} .53^{*}$ & .25 & .17 & .15 & $.59^{*}$ & 1 & & & & & \\
\hline IR & $.55^{* *}$ & $.70^{* *}$ & $.65^{* *}$ & $.59^{*}$ & $.41^{* *}$ & $.65^{* *}$ & $.48^{*}$ & $.43^{*}$ & $.50^{* *}$ & 1 & & & & \\
\hline CR & $.54^{* *}$ & $.63^{* *}$ & $.66^{* *}$ & $.40^{*}$ & $.51^{* *}$ & .10 & .02 & .09 & .3 & .25 & 1 & & & \\
\hline ER & $.44^{* *}$ & $.57^{* *}$ & .34 & $.65^{*}$ & $.58^{* *}$ & $.61^{* *}$ & .33 & .37 & $.50^{* *}$ & .14 & .21 & 1 & & \\
\hline SR & $.47^{* *}$ & $.35^{* *}$ & $.66^{* *}$ & .21 & .15 & .02 & .19 & $.44^{*}$ & .13 & .22 & .03 & .10 & 1 & \\
\hline FR & .23 & .16 & .34 & .23 & $.45^{* *}$ & .05 & .21 & .11 & .30 & .15 & $.41^{* *}$ & .05 & .17 & 1 \\
\hline
\end{tabular}

**Correlation is significant at the 0.01 level (2-tailed).

For partnership and resources it has strong positive relationship with the four types of innovations and the correlation values are all significant for SI,PI,MI,OI i.e..64,.51,.65,..57 respectively, which shows that firms where partnership and resources techniques are used for quality improvement i.e. firm makes strong relationship with its suppliers the firm innovation results also improves but the relationship of partnership and resources PR is weak with other quality practices ML, EM, PS i.e..10,.22,.34. For process management it has strong positive relationship with the four types of innovations and the correlation values are all significant for SI,PI,MI,OI i.e. 57,.67,.46,.53 respectively, which shows that firms where process 
management techniques are used for quality improvement the firm innovation results also improves but the relationship of process management is weak with other quality practices ML, EM, PS, i.e..25,.17,.15, except with PR the correlation value is.59 which shows that the process management techniques have a positive effect on firm efforts to make good relations with its suppliers. The correlation coefficient values for performance results are divided into innovation results, customer results, employee results, society results and financial results and the values for innovation results IR show that the firm innovation activities have a more strong positive relationship with it then with firm's quality improvement activities SI,PI,MI,OI i.e. .55,.70,.65,.59 especially for PI and EM and the values for customer results CR show that the firm innovation activities have a more strong positive relationship with it then with firm's quality improvement activities SI,PI,MI,OI i.e. .54,.63,.66,.40. While employee result has more positive relationship with both firm's innovation activities and quality improvement practices. For society results it has more positive correlation with service innovation and marketing innovation with values i.e. 47,.66. The firm financial results show weak relationship with all other innovation and quality constructs except with management leadership with correlation value of.45.

Table 5. Regression Analysis for innovation, quality practices and firms performance

\begin{tabular}{|l|l|l|l|l|}
\hline Model & $\mathbf{R}$ & R Square & $\begin{array}{l}\text { Adjusted } \\
\text { Square }\end{array}$ & $\begin{array}{l}\text { Std. Error of the } \\
\text { Estimate }\end{array}$ \\
\hline 1 & .475 & .331 & .399 & 1.928 \\
\hline
\end{tabular}

a. Predictors: (Constant), SI,PI,MI,OI,ML,EM,PS,PR,PM

b. Dependent Variable: Composite Firm

Performance(IR+CR+ER+SR+FR)

\section{Coefficients}

\begin{tabular}{|l|l|l|l|l|l|}
\hline Model & \multicolumn{2}{l}{$\begin{array}{l}\text { Un standardized } \\
\text { Coefficients }\end{array}$} & $\begin{array}{l}\text { Standardized } \\
\text { Coefficients }\end{array}$ & t & Sig. \\
\hline & B & Std. Error & Beta & & \\
\hline (Constant) & .614 & .844 & & 2.843 & .005 \\
\hline SI & .175 & .235 & -.061 & -.746 & .457 \\
\hline PI & .300 & .320 & .107 & .937 & .350 \\
\hline MI & .546 & .322 & .170 & 1.699 & .091 \\
\hline OI & .389 & .306 & -.181 & -1.270 & .205 \\
\hline ML & .215 & .234 & .102 & .921 & .358 \\
\hline EM & .315 & .255 & .110 & 1.201 & .007 \\
\hline PS & .256 & .302 & .091 & .809 & .236 \\
\hline PR & .400 & .344 & .151 & .988 & .342 \\
\hline PM & .199 & .207 & .113 & 1.043 & .097 \\
\hline
\end{tabular}

a. Dependent Variable: Composite Firm Performance (IR+CR+ER+SR+FR)

From table 5 we can see that the value of regression coefficient $\mathrm{R}$ is.475 which shows that almost $47 \%$ change in firm's performance that is our dependent variable is because of the 
variables that we have considered in our model which is an acceptable level for the strength of the model.

\section{Discussion}

From this study we have found important relationships among different innovation types and quality practices in the service sector firms of Pakistan. Based on the analysis we find out that management leadership, employee management techniques, policy and strategy for quality affects broader areas of the organizational settings so they have a stronger affect on the firm's organizational innovations. And marketing innovation has a more stronger affect on firms customer results and society results as marketing innovations can help the firms to create a better image for its current and potential customers and helps in improving the company overall image in the society while the data shows that service and process innovation has a more strong affect on innovation results and customer results. From the data we can see that employee results and innovation results are affected more through management leadership and employee management practices because in firms where top management is committed to quality and reward innovative ideas the employees of such firms usually show higher performance and creativity which is also supported by previous empirical researches as well like Hung (2009), Tether (2003) and Miles (2000). When we look at the data for financial results of the firm and its relationship with quality practices and various types of innovation we see a very weak relationship which may be explained by the fact that in actual business environment there are many other factors which have strong affect on firms financial performance that includes government policies, competitors action and many others, and since most firms in the sample belong to the public sector where the main objective of the firms is to achieve better performance in terms of delivering satisfactory and high quality services then achieving financial targets and similar findings were made by Zehir (2010) and Leticia(2007).

\section{Limitations of the study}

There are a few limitations of this study firstly due to lack of resources and time constraints the study has collected data from a smaller number of service firms but in the future a larger sample size can further validate the accuracy of results. Secondly the model of this study is rather simple and do not consider any moderating variables that can modify the relationship between different innovation types and quality practices so there is still room for contribution by future researches in this area.

\section{References}

Abrunhosa A, \& Moura P. (2008). Are TQM Principles supporting innovation in the Portuguese industry. Technovation, 28, 208-221.

http://dx.doi.org/10.1016/j.technovation.2007.08.001

Carlos J, Leusar B, Ana B, \& Tena E. (2009). An empirical assessment of the EFQM Model, Evaluation as a TQM framework relative to the MBNQA Model. Journal of Operations Management, 27, 1-22. http://dx.doi.org/10.1016/j.jom.2008.04.001 
Chen, J.K. (2009). TQM measurement model for the biotechnology industry in Taiwan. Expert Systems with Applications, 36, 8789-8798. http://dx.doi.org/10.1016/j.eswa.2008.11.013

Drucker P.F. (2003). The essential Drucker: The best of sixty years of Peter Drucker's essentials writings on management, New York, Collins p. 130.

Fotopoulus C.B., \& Posmas E.L. (2009). The impact of soft \& hard TQM elements on quality management results. International Journal of Quality and Reliability Management, 26(2), 150-163. http://dx.doi.org/10.1108/02656710910928798

Gallouj, F., \& Djellal, F. (2010). Innovation in services. Research Policy, 26(4-5), 537-556.

Gault, F. (2012). User innovation and the market. Science and Public Policy, 39, 118-128. http://dx.doi.org/10.1093/scipol/scs005

Gill,J. (2009). Quality follows quality; add quality to the business and profits will multiply. The TQM Journal, 21(5), 530-539. http://dx.doi.org/10.1108/17542730910983434

Hipp C, Thether B.S., \& Miles. (2000). The incidence and effect of innovation in services. International journal of Innovation Management, 4(4), 417-453.

Hung S.W. (2009) Development and innovation in the IT industries of China and India. Technology in Society, 31, 29-41. http://dx.doi.org/10.1016/j.techsoc.2007.12.009

Koch, P., \& Hauknes, J. (2005). Innovation in the public sector. International Journal of Quality and Reliability Management, 36, 154-170.

Kumar R, Garg D, \& Grag T.K. (2009). Total quality management in Indian industries: relevance, analysis and directions. The TQM Magazine, 21(6), 607-622. http://dx.doi.org/10.1108/17542730910995873

Leticia M. S.V. (2007). TQM and Firms performance: An EFQM excellence model research based survey. Journal of Business Science \& Applied management, 2(2), 11-31.

Miles, I. (2007). R\&D beyond manufacturing: the strange case of services' $R \& D$. $R \& D$ Management, 37(3), 249-268. http://dx.doi.org/10.1111/j.1467-9310.2007.00473.x

Oslo Manual. (2005). A joint publication of OECD and EURO Stat, $3^{\text {rd }}$ Edition, Chapter 3, pp 47-48.

Parast M.M. (2010). The effect of six sigma projects on innovation and firm performance. International Journal of Project Management, 7, 1-11.

Pinho J.C. (2008). TQM and performance in small medium enterprise. International Journal of Quality and Reliability Management, 25(3), 256-275. http://dx.doi.org/10.1108/02656710810854278

Porter M. E. (1991). Towards a dynamic theory of strategy. Strategic Management Journal, 12, 95-117. http://dx.doi.org/10.1002/smj.4250121008 


\section{Macrothink}

Journal of Management Research

ISSN 1941-899X

2014, Vol. 6, No. 4

Prajogo D.I. (2006). The relationship between organization strategy, TQM, and organization performance. European Journal of Operations Management, 168, 35-50. http://dx.doi.org/10.1016/j.ejor.2004.03.033

Psychogios A. G. (2010). Restructuring the employment relationship in South Eastern Europe, total quality based changes on manager's careers and job security, Employee Relations. Qualitative report, 32(3), 310-327.

Rycroft R.W. (2006). Time and technological innovation, Implications for public policy. Technology in Society, 28, 281-301. http://dx.doi.org/10.1016/j.techsoc.2006.06.001

Sadikoglu E., \& Zehir C. (2010). Investigating the effect of innovation and employee performance on relationship between TQM practices and firm performance, An empirical study of Turkish firms. International Journal of Production Economics, 12, 1-14.

Sila I. (2007). Examining the effect of contextual factors on TQM and performance through the lens of organizational theories. Journal of operations management, 25, 83-109. http://dx.doi.org/10.1016/j.jom.2006.02.003

Singh P.J, \& Smith A.J.R. (2004). Relationship between TQM and innovation: An empirical study. Journal of Manufacturing Technology Management, 15(5), 394-401. http://dx.doi.org/10.1108/17410380410540381

Tether, B.S. (2003). The sources and aims of innovation in services: variety between and within sectors. Economics of Innovation and New Technology, 12, 481-505. http://dx.doi.org/10.1080/1043859022000029221

Windrum, P., \& Koch, P. (2008). Innovation in Public Sector Services. Entrepreneurship, Creativity and Management. Research Policy, 37, 649-672. http://dx.doi.org/10.1016/j.respol.2007.12.011 